This is the version of the article accepted for publication in Nordic Journal of International Law published by Brill https://doi.org/10.1163/15718107-08501001

Accepted version downloaded from SOAS Research Online: http://eprints.soas.ac.uk/31070/

\title{
Loss and Damage from the Impacts of Climate Change: A Framework for Implementation
}

\section{Birsha Ohdedar}

This is a pre-publication version of: Birsha Ohdedar, 'Loss and Damage from the Impacts of Climate Change: A Framework for Implementation’ (2016) 85(1) Nordic Journal of International Law 1, available from:

http://booksandjournals.brillonline.com/content/journals/10.1163/1571810708501001

\begin{abstract}
Loss and damage from the impacts of climate change affect many countries and communities across the world. In 2013, the Warsaw Mechanism on Loss and Damage, created through the United Nations Framework on Climate Change, established an institutional process to respond to such impacts. This paper aims to contribute to the growing literature on climate liability by outlining a normative framework based on international law that can be used as a guiding path for the mechanism. It is argued that addressing loss and damage in line with these core principles and international law is required to develop a robust and legitimate mechanism. This framework is then used to answer critical questions regarding an international loss and damage mechanism for climate change.
\end{abstract}

\section{Introduction}

The impacts of climate change are already causing loss and damage to vulnerable communities and societies. Over the past twenty years there has been much discussion on how we can shift our economies and lifestyles to prevent the damaging impacts of climate change. Overall, these discussions have failed to adequately curb emissions and the impacts of climate change are now being felt. These impacts include ecological harm, floods, droughts, the rise of sea levels, increased frequency of heat waves, as well as the human cost of death, disease and displacement. ${ }^{1}$ There is no

\footnotetext{
${ }^{1}$ M.L. Parry, O.F. Canziani, J.P. Palutikof, P.J. van der Linden and C.E. Hanson (eds), IPCC, "Summary for Policymakers," in Climate Change 2007: Impacts, Adaptation and Vulnerability. Contribution of Working Group II to the Fourth Assessment Report of the Intergovernmental Panel on
} 
international mechanism responsible for addressing losses from such impacts. Despite continued discussion and attempts to adapt to climate change, many communities will not be protected from the disastrous impacts of climate change.

In 2013, State Parties to the United Nations Framework Convention on Climate Change ${ }^{2}$ (henceforth 'UNFCCC' or 'Convention'), agreed to the Warsaw International Mechanism (henceforth 'Warsaw Mechanism'). The Warsaw Mechanism is the beginning of a process for further action to address loss and damage arising from climate change, something that vulnerable developing countries have been advocating for the past 20 years. ${ }^{3}$

The main objective of this paper is to analyse the ethical and legal underpinnings of such a loss and damage mechanism and put forward a 'working framework', based on normative and legal arguments, which can underpin discussions. This paper aims to advocate for a loss and damage mechanism with an ethical grounding by both justifying a loss and damage mechanism and suggesting reforms which seek to improve the international system ultimately bringing it closer with what arguably are its core values.

A normative framework, based on international law, is necessary to give the mechanism legitimacy. It will provide a legal underpinning to the mechanism, which will strengthen the UNFCCC process. Such a framework will provide a clear platform for discussions. As UNFCCC negotiations over the last 20 years have shown, processes under the treaty can take several iterations and many years of dialogue to gain momentum. Therefore, a framework provides overarching goals and parameters for a loss and damage mechanism.

The first section of this paper will set out the background to loss and damage, including a brief history of how the negotiations around a loss and damage

Climate Change, Summary for Policymakers (Fourth Assessment Report) (Cambridge University Press, 2007) 7-22.

${ }^{2}$ United Nations Framework Convention on Climate Change (adopted 9 May 1992, entered into force 21 March 1994) 1771 UNTS 107. (UNFCCC)

${ }^{3}$ See for example AOSIS submission in 1991: AOSIS, Submission to the Intergovernmental Negotiating Committee for a Framework Convention on Climate Change (A/AC.237/WG.II/CRP.8, 17 December 1991). (AOSIS 1991 Proposal) 
mechanism have evolved. It will then seek to answer two key questions: what is the ‘justice imperative’ for a loss and damage mechanism at the international level? And, is there a basis under international law for such a mechanism? Drawing on these discussions, the paper will attempt to set out a coherent framework to create a 'just regime' to address loss and damage. Finally, keeping this framework in mind, the paper will seek to answer some further pertinent questions regarding an international loss and damage mechanism. 


\section{What is Loss and Damage?}

Defining loss and damage is an on going process; it is more complex than encapsulated in one single definition. Loss and damage has been described as impacts which are "beyond adaptation", ${ }^{4}$ or as "residual damage". ${ }^{5}$

The working glossary for loss and damage at regional meetings provides that 'damage' can be thought of as “negative impacts that can be repaired or restored (such as windstorm damage to the roof of a building or damage to a coastal mangrove forest from coastal surges which affect villages).” 6 'Loss' refers to negative impacts that cannot be repaired or restored, such as loss of geological freshwater sources related to glacial melt, desertification, and loss of culture or heritage associated with potential population redistribution. $^{7}$

According to Gall and Kreft, what constitutes loss and damage varies and can include "economic and non-economic, tangible and intangible, as well as reversible and irreversible impacts such as fatalities, destruction of infrastructure, homes, and crops, contamination of drinking water, habitat loss, and more." ${ }^{8}$ Such damage can be caused by extreme weather events or slow onset events. The international community has little experience addressing slow onset events in particular. ${ }^{9}$

Loss and damage must also be seen in light of temporal and spatial dimensions. It reflects the historical and present manifestations of climate change, but also incorporates

\footnotetext{
${ }^{4}$ Bolivia, 'Theme III - The Role of the Convention in enhancing the implementation of approaches to address loss and damage associated with the adverse effects of climate change', Submission to the UNFCCC, 7

November 2012, <unfccc.int/files/documentation/submissions_from_parties/application/pdf/bolivia_et_al.pdf> accessed 1 September 2013.

${ }^{5}$ Richard S.J Tol and Roda Verheyen, 'State Responsibility And Compensation For Climate Change Damages-A Legal And Economic Assessment’ (2004) 32 Energy Policy.

${ }^{6}$ UNFCCC, Background paper to the Regional expert meeting on: A range of approaches to address loss and damage associated with the adverse effects of climate change, including impacts related to extreme weather events and slow onset processes, 23-25 July 2012,

$<$ unfccc.int/files/adaptation/cancun_adaptation_framework/loss_and_damage/application/pdf/20120718_fourth_ order_draft_lit_review_unu_ra_lsf.pdf> accessed 1 September 2013.

7 ibid.

${ }^{8}$ Melanie Gall and Sonke Kreft, 'Measuring What Matters? A Suitability Analysis of Loss and Damage Databases for the Climate Change Convention Process’ (2013) 6 Loss and Damage <www.loss-anddamage.net/download/6845.pdf> accessed 6 August 2013.

${ }^{9}$ Sonke Kreft, 'Overview and Summary of Party Submissions on the Role of the Convention', (2012) 4 Loss and Damage <www.lossanddamage.net/download/6868.pdf> accessed August 1, 2013.
} 
future potential losses. Currently, loss and damage is largely a local issue, such as the impacts described in the case study above. However future loss and damage is of potentially unimaginable magnitude due to the interconnectivity of impacts leading to cascading transnational events, such as impacts on trade, supply networks, value added chains as well as non-economic values, such as climate migration, displacement, and the loss of culture. The interconnectivity of impacts and the causes of climate change require a global response to address loss and damage.

\subsection{UNFCCC and Loss and Damage}

Mechanisms to address loss and damage have been discussed at global climate change meetings for more than 20 years, albeit with varying degrees of importance in the agenda. The first proposals for a mechanism came back in 1991 from the Alliance of Small Island States (henceforth 'AOSIS'), during the course of negotiations for the UNFCCC (henceforth ‘1991 AOSIS Proposal’).

The 1991 AOSIS Proposal was significantly forward looking. Verheyen states that the proposal would have established quite a flexible and cooperative regime. ${ }^{10}$ However, at that early stage, other State Parties were unwilling to engage in any discussion of liability and compensation. This still remains the position of many industrialised countries. However, the science is much clearer, and the impacts of climate change are are more present today than in 1991.

For much of the 1990s and 2000s, mitigation was the dominant topic of discussion on climate change. Adaptation, and its corollary loss and damage, were given relatively little attention until the mid-2000s. The IPCC Fourth Assessment Report in 2007 made it clear that current greenhouse gas (henceforth 'GHG') reduction commitments were far too conservative, and loss and damage from climate change was inevitable. ${ }^{11}$ At this stage discussions on managing loss and damage re-entered the debate. The 2007 'Bali Action Plan'12, as well as the agreed Cancun Adaptation Framework ${ }^{13}$ (henceforth 'Cancun

\footnotetext{
${ }^{10}$ ibid.

${ }^{11}$ Fourth Assessment Report.

${ }^{12}$ UNFCCC, Decision 1/CP13, ‘Bali Action Plan’, (UNFCCC/CP/2007/6/Add.1, 14 March 2008) Article 1(c) (ii). (Bali Action Plan)

${ }^{13}$ UNFCCC, Decision 1/CP16, 'The Cancun Agreements: Outcome of the work of the Ad Hoc Working Group on Long-term Cooperative Action under the Convention' (UN Doc. FCCC/CP/CP/2010/7/Add.1, 15 March 2011) Para 19. (Cancun Agreements)
} 
Framework') started a process of looking into loss and damage again through insurance mechanisms and other risk reduction strategies.

At COP 18 in 2012, the issue of loss and damage was debated, and it was agreed that institutional arrangements "such as an international mechanism” were to address loss and damage in developing countries that are particularly vulnerable to the adverse effects of climate change be agreed at COP $19 .{ }^{14}$

This led to the Warsaw Mechanism, which has set up a framework that can be now used by vulnerable developing countries to push for further action on loss and damage. Broadly, the Warsaw Mechanism will carry out three types of functions related to:

1. enhancing knowledge and understanding of comprehensive risk management approaches;

2. strengthening dialogue, coordination, coherence, and synergies among relevant stakeholders; and

3. enhancing action and support as to enable countries to take action to address loss and damage.

Though many of the perspectives from the international media focussed on the fact that there was no compensation or liability mechanism established, it is important to recognise that the Warsaw Mechanism further opened the possibility of compensation or liability being included in the future. A mechanism needs to develop and operationalise before conclusions on its effectiveness can be drawn. Further, such criticism also fails to highlight that loss and damage is a complex issue. The Warsaw Mechanism provides a way to bring further knowledge and action on a number of issues, such as long term adverse effects of climate change, slow onset impacts, loss of livelihood, loss of ecosystems and others.

Outside of the Warsaw Mechanism, AOSIS remains the only party to have put forward a comprehensive loss and damage proposal. ${ }^{15}$ In 2008, AOSIS proposed a "MultiWindow Mechanism to Address Loss and Damage from Climate Change Impacts” to the

\footnotetext{
${ }^{14}$ UNFCCC, Decision 3/CP.18, 'Approaches to Address Loss and Damage Associated with Climate Change Impacts in Developing Countries that are Particularly Vulnerable to the Adverse Effects of Climate Change to Enhance Adaptive Capacity'(UN Doc. FCCC/CP/2012/8/Add.1, 28 February 2013) para 9.

${ }^{15}$ AOSIS 1991 Proposal.
} 
Adaptation Working Group (henceforth '2008 AOSIS Proposal'). ${ }^{16}$ Building on the 1991 AOSIS Proposal, the 2008 AOSIS Proposal has three inter-dependent components: an insurance component, a rehabilitation and compensatory competent, and a risk management component. The 2008 AOSIS Proposal put forward a proposed adaptation specific fund under the UNFCCC ${ }^{17}$ as the preferable option for funding, as assessed through contributions based on the level of countries' GHG emissions, their respective capabilities, and their historic responsibilities. It also suggested other sources of funding, such as bilateral donors and the Kyoto Protocol.

The 2008 AOSIS Proposal was put forward before the Cancun Framework and was therefore part of a wider mechanism to address adaption. Since 2008, both the adaptation and loss and damage programmes have moved forward. However, both the 2008 and 1991 AOSIS Proposals' remain extremely helpful blueprints for the development of the Warsaw Mechanism.

\footnotetext{
${ }^{16}$ AOSIS, Multi-Window Mechanism to Address Loss and Damage from Climate Change Impacts (Proposal to the Ad hoc Working Group on Long-term Cooperative Action under the Convention, 6 December 2009) <unfccc.int/files/Kyoto_protocol/application/pdf/aosisinsurance061208.pdf> accessed 1 August 2013.

${ }^{17}$ Currently such a fund exists under the Kyoto Protocol.
} 


\section{What is the justice imperative for an International Loss and Damage Mechanism?}

Baskin defines climate justice as something beyond and different from the notion of climate law, looking at the extent to which our responses to climate change are "fair and equitable." ${ }^{18}$ Climate justice is linked to how climate change is associated with broader issues of inequalities in wealth and wellbeing and addresses the asymmetries between those who are responsible for climate change and those who will bear the burdens of damage associated with climate change. ${ }^{19}$ This paper will specifically look at what theories of climate justice can apply in relation to a loss and damage mechanism.

\subsection{Corrective Justice}

At a basic level, any system of loss and damage involves correcting the wrong that has occurred (climate damage), by providing a remedy for it whether monetarily or by other means. Corrective justice is viewed as necessary to equalise a gain by a party who causes an injustice and the law, through a judiciary, imposes a penalty to correct the inequality that has occurred. ${ }^{20}$ This concept of corrective justice informs tort law, which is based on a foundation of corrective justice and compensating to victims for the damage that tortfeasors have caused. For climate change loss and damage, tort law can be seen as an appropriate normative framework for addressing damages and is particularly suitable to compensate for injury to economic interests related to property rights. ${ }^{21}$

Corrective justice has already influenced climate policies and measures. Maguire and Lewis argue that the Green Climate Fund and the proposed loss and damage mechanism are both influenced by theories of corrective justice. ${ }^{22}$ In relation to loss and damage, the authors point out that pooled insurance models, such as that proposed as a component of the 2008 AOSIS Proposal, primarily seek to ensure that a remedy is provided when harm is suffered, thus insurance is based on the influence of corrective justice. ${ }^{23}$ Corrective justice will

\footnotetext{
${ }^{18}$ Jeremy Baskin, ‘The Impossible Necessity of Climate Justice?’ (2009) 10/2 Melbourne Journal of International Law <www.law.unimelb.edu.au/files/dmfile/download887b1.pdf> accessed 4 April 2014.

${ }^{19}$ Neil Adger, Jouni Paavoal and Saleemul Huq, 'Towards Justice in Adaptation to Climate Change,' in Neil Adger et al. (eds.), Fairness in Adaptation to Climate Change (MIT Press, 2006) 4.

${ }^{20}$ W.D Ross, J. L. Ackrill, and J. O. Urmson, The Nicomachean Ethics (Oxford University Press, 1998) 106.

${ }^{21}$ Philippe Cullet, 'Liability and Redress for Human-Induced Global Warming - Towards an International Regime' (2007) 43A Stan.J.Int'l L. 99, 109.

${ }^{22}$ Rowena Maguire and Bridget Lewis, 'The Influence of Justice Theories on International Climate Policies and Measures’ (2012) 8(1) MqJICEL (2012) 16, 26.

${ }^{23}$ ibid.
} 
underpin any loss and damage mechanism and requires three elements: a responsible party, a victim, and damage.

\subsection{Responsibility and Vulnerability: 'Who Pays', 'Who Claims', and 'What Can Be Claimed'}

Under any model of corrective justice, those who have caused damage have a duty to compensate those who have suffered harm. On the other hand, claimants are generally entitled to damages because they are victims of an injustice and the remedy seeks to restore victims to the condition that they were in before the unjust activity occurred or provide compensation for the harm that has occurred. Thus, an international loss and damage mechanism will need to determine who is responsible and who is eligible to claim compensation.

Climate change sees a vast disjuncture between those who have been responsible for GHG emissions, both historically and currently, and those who continue to suffer most from its harmful effects. The unjust distribution of climate change has two sides. First, the physical impacts of climate change are felt unevenly across the world. For example, countries such as Bangladesh or Tuvalu have very little responsibility for GHG emissions but will face a greater impact of sea level rise. Conversely others, such as the United States or parts of Western Europe, have contributed far greater in terms of emissions but face less immediate threat of impacts. ${ }^{24}$ Second, many of the countries who are most vulnerable are also economically weak and do not have the capacity to deal with the impacts of climate change.

The concept of vulnerability and its linkages with resilience and adaptation are central to a loss and damage mechanism. Vulnerability equates to both physical and economic insecurity arising from the impacts of climate change. ${ }^{25}$ In turn, the concept of 'resilience', which is comes from physical sciences, denotes the ability to anticipate, absorb, accommodate or recover from the effects of a hazardous event. ${ }^{26}$ The impacts of climate change will increase vulnerability, however other human and natural systems also contribute to greater exposure and vulnerability. The IPCC SREX Report points out that individuals and

\footnotetext{
${ }^{24}$ See for example, climate vulnerability maps on - Center for Global Development, Mapping the Impacts of Climate Change <www.cgdev.org/page/mapping-impacts-climate-change> accessed 31 August 2013.

25 IPCC, 'Summary for Policymakers,' in Managing the Risks of Extreme Events and Disasters to Advance Climate Change Adaptation (Cambridge University Press, 2012) 3. (SREX Report)

${ }^{26}$ ibid.
} 
communities are differentially exposed and vulnerable based on a range of factors such as levels of wealth, education, health status, gender, age and class. ${ }^{27}$ Factors such as socioeconomic conditions, urbanisation, housing policies as well as physical geography of human settlement contribute to exposure and vulnerability and can differ among regions and countries. ${ }^{28}$ Accordingly, vulnerability must be viewed as varying across temporal and spatial scales. This complicates pinpointing specific groups that are at highest risk and quantifying exact vulnerability. ${ }^{29}$ Rather, a broad approach under scientific consensus shows which areas are likely to experience certain types of climate change and extreme events. These include Small Island Developing States (henceforth 'SIDS'), water scarce and food insecure areas, and places with high population densities concentrated in coastal areas. ${ }^{30}$

Reducing vulnerability and increasing resilience is a key aim of climate change adaptation and more generally of disaster management. Climate change adaptation policies and a range of other processes (such as economic policies) will play an integral role in reducing vulnerability and building resilient societies. Such policies can reduce the need for further loss and damage claims. From this perspective, a loss and damage mechanism can be viewed as the negative outcome of exposure to environmental hazards and the lack of resilience of a community to manage them. ${ }^{31}$ Loss and damage then serves as an important link to evaluate the benchmarks for climate change adaptation and an integral part of vulnerability and resilience analyses. ${ }^{32}$

Under a climate change damages mechanism, Dow, Kasperson, and Bohn argue that there is a moral imperative for giving most vulnerable communities special attention. ${ }^{33}$ This position has the philosophical underpinning of John Rawls, who posits that a ‘just society’ is one that is arranged in such a way that the position of the least advantaged is optimised. ${ }^{34}$ It is

\footnotetext{
27 ibid.

${ }^{28}$ ibid.

${ }^{29}$ Kristin Dow, Roger E. Kasperson, and Maria Bohn, 'Exploring the Social Justice Implications of Adaptation and Vulnerability', in Neil Adger et al. (eds), Fairness in Adaptation to Climate Change (MIT Press, Cambridge, 2006), p. 86.

${ }^{30}$ Dow, Kasperson, and Bohn (n 29) 87.

31 Andrew Fekete and Patrick Sakdapolrak, 'Loss and Damage as an Alternative to Resilience and Vulnerability? Preliminary Reflections on an Emerging Climate Change Adaptation Discourse’ (2014) 5 Int J Disaster Risk Sci 88.

32 ibid.

33 Dow, Kasperson, and Bohn (n 29) 85.

${ }^{34}$ See for example: J. Rawls, A Theory of Justice (Belknap Press of Harvard University Press, 1971). And Pogge's extension of Rawls to the international scale, see T. Pogge, Realizing Rawls (Cornell University Press, 1989).
} 
also reflected in the principle of 'priority', under international environmental law. Principle 6 of the Rio Declaration on Environment and Development in 1992 (henceforth 'Rio Declaration') states that priority should be given to the needs of developing countries, “particularly the least developed and those most environmentally vulnerable.”35 The priority principle is also reflected throughout the UNFCCC, which has numerous references to prioritising vulnerable nations, namely Least Developed Countries (henceforth 'LDCs') and SIDS.

The above discussions oblige further questions when examining responsibility and vulnerability for nations under a global governance framework. Firstly, how do we create subsets of countries that are burdened with responsibility ('who pays') and with vulnerability ('who claims')? Secondly, how do we deal with inequalities that exist within countries? Finally, what loss and damage can be claimed in a loss and damage mechanism ('what can be claimed')?

\subsubsection{Defining the Parties}

Principles of environmental justice, namely the concepts of 'polluter-pays', and 'common but differentiated responsibility and respective capabilities' (henceforth 'CBDRRC') can assist in defining parties to an international loss and damage mechanism.

The polluter-pays principle is a norm of international environmental law as reflected under Principle 16 of the Rio Declaration. The principle simply asserts that the party responsible for damage, due to certain polluting activities, pays the cost of damage to the natural environment. This principle correlates with corrective justice and tort law's principle of holding a wrongdoer to account. It is also consistent with principles of distributive justice, as polluters deserve to have greater responsibilities for the problems they have caused. ${ }^{36}$

The principle of CBDRRC accords responsibility by accounting the historical polluting activities and the economic capabilities of nations. CBDRRC is expressed in Principle 7 of the Rio Declaration and in Article 3.1 of the UNFCCC. Its philosophical basis

\footnotetext{
${ }^{35}$ UNCED, Rio Declaration on Environment and Development, (UN Doc. A/CONF.151/26/Rev.1 (Vol. 1), Annex I, 28 September 1992). (Rio Declaration)

${ }^{36}$ D. Brown, Climate Change Ethics: Navigating the Perfect Moral Storm, (Routledge, 2013) 168.
} 
can be traced to two notions of equity. The first notion of equity is the issue of an unequal distribution from climate change causing activities. The notion, discussed earlier, that a damaging party has benefited disproportionately from the industrialisation process, historically reliant on climate change causing activities; yet since the damage is universal, the costs are borne by everyone. ${ }^{37}$ This is linked to the legal principle of 'common heritage and common concern' that the environment belongs to all of us and needs to be held in trust for future generations. The second notion of equity is that countries that face the brunt of the damage do not have the capacity to adapt to its impacts or solve the environmental problem. Equity in this sense means that the inequalities between nations are taken into account in determining levels of commitments between different states. ${ }^{38}$

Through the concept of polluter-pays and CBDRRC, the climate change regime has divided countries into categories of 'developed' and 'developing', or 'Annex' and 'nonAnnex' to appropriate responsibility. However, CBDRRC has become contentious regarding the responsibility and capabilities of large developing countries namely China, Brazil and India. These countries have rapidly developed in the last 20 years and their total emissions have risen sharply. Accordingly, developed countries have consistently lobbied for greater responsibilities to be apportioned to them. The current homogeneity in treating developing countries as a large bloc means that China, for example, has the same responsibilities and capabilities as Malawi or Palau, despite far greater emissions and less economic vulnerability. Furthermore, countries in the South are not homogenous in their interests regarding climate change, such as the gulf between SIDS and the petroleum exporting states.

With respect to vulnerability, a tension exists between creating a subset of countries able to claim compensation and the ubiquity of vulnerability. This is not to say that all countries face the same vulnerability, but rather that all countries are vulnerable to climate change. As the Cancun Framework states “adaptation is a challenge faced by all Parties”39 whether the Parties are wealthy developed countries, large developing countries, LDCs, or SIDS. Recent examples of damages, which are attributed to climate change, have been felt by a variety of states and peoples. In 2012 and 2013 alone, countries such as India, the United

\footnotetext{
${ }^{37}$ L. Rajamani, 'The Principle of Common but Differentiated Responsibility and the Balance of Commitments under the Climate Regime’ (2000) 9(2) RECIEL 120, 123.

38 ibid.

${ }^{39}$ Cancun Agreements (n 13) para 11.
} 
States, and the Marshall Islands were hit by devastating impacts of extreme weather attributable to climate change. ${ }^{40}$

Emphasising the concept of common heritage of mankind for a liability mechanism is one way of avoiding state-centric groupings. Taylor argues that a climate liability regime should define 'affected state' as any state that brings forward an action in the collective interest of the 'global commons'. ${ }^{41}$ The atmosphere is thus assumed to be part of the global commons, and any state can seek compensation, circumventing any ethical uncertainties regarding divisions between countries. Taylor suggests a 'balance of interest' test for the hypothetical tribunal body, with an important flexibility to "take into account particular interests of developing states". ${ }^{42}$

Other critics argue that a polluter-pays approach, based on historic emissions, is not applicable for climate change. ${ }^{43}$ Cosmopolitan ethicists such as Posner and Sunstien argue that holding people responsible for past emissions, which were caused by their dead ancestors, or perhaps not even their own ancestors (citing the mobility of citizens through countries) is not equitable. ${ }^{44}$ They argue against state-centric responsibility, suggesting that there is a lack of culpability because past emitters were not aware, or did not have scientific certainty, over the impacts of their activities. ${ }^{45}$ Similarly, Caney argues that individuals, corporations, and other economic entities have a burden to share in climate change. ${ }^{46}$ Caney posits a liability regime based on a combination of polluter-pays and CBDRRC, which rests on polluters whether they are individuals, corporates, or states. Under Caney's liability regime, those who exceed their GHG quotas have a duty to compensate; however the most

\footnotetext{
${ }^{40}$ J. Serna, 'Hurricane Sandy Death Toll Climbs Above 110, N.Y Hardest Hit', L.A Times, 3 November 2012, $<$ http://articles.latimes.com/2012/nov/03/nation/la-na-nn-hurricane-sandy-deaths-climb-20121103> accessed 1 September 2013; 'Uttarkhand: 5000 feared killed, 19,000 still stranded', Times of India, 23 June 2013, <articles.timesofindia.indiatimes.com/2013-06-23/india/40146595_1_kedarnath-gaurikund-badrinath> accessed 1 September 2013; J. Parnell, 'Tides Swamp Climate Vulnerable Marshall Islands,' Rtcc.org, 28 June 2013, $<$ www.rtcc.org/2013/06/26/tides-swamp-climate-vulnerable-marshall-islands/> accessed 1 September 2013.

${ }^{41}$ Prue Taylor, An Ecological Approach to International Law: Responding to the Challenges of Climate Change (Routlege, 1998) 177-180.

42 ibid 179.

${ }^{43}$ Eric Posner and Carl Sustien, ‘Climate Change Justice’ (2008) 96 Geo.L.J 1565, 1593.

44 ibid.

45 ibid 1583-1602.

${ }^{46}$ Simon Caney, 'Cosmopolitan Justice’ in Stephen Gardiner et al. (eds), Climate Ethics: Essential Readings, (Oxford University Press, 2010)135-136.
} 
advantaged also have a further duty to address the impacts of climate change because they have the 'ability to pay’ rather than responsibility based on historic emissions. ${ }^{47}$

However, both Taylor's approach and the cosmopolitan approaches do not consider historic emissions. Historic emissions are responsible for much of the damage today and it cannot be equitable to simply discount responsibility for such a large contribution to damage. Today's generation living in the global North have benefitted disproportionately from those polluting activities. According to the World Resources Institute, the Untied States, Europe, and the former Soviet Union are responsible for around 70 per cent of all $\mathrm{CO}_{2}$ emissions in the $20^{\text {th }}$ century. ${ }^{48}$ Moral culpability is also justified. Since the $1990 \mathrm{~s}$, there has been scientific consensus on the effects of GHG emissions, yet there has been no slow down in emissions by those countries that are the largest polluters. ${ }^{49}$ Accordingly, moral culpability can be justified and, as Brown states, "at a minimum, be calculated for the point in time that nations should have known that emitting greenhouse gases could cause climate change harms." 50

A response to climate change and loss and damage must consider the unique spatial and temporal characteristics of the issue. Therefore, a loss and damage mechanism must consider historic, current, and future contributions to GHG emissions. The polluter-pays principle demands responsibility to be accorded in such a way to account for new polluters. Historic responsibility needs to be weighed against the economic capability of countries to have reduced emissions since scientific consensus. Differentiation therefore needs to move from static to dynamic groups to reflect the changes in the world in both responsibility and capabilities. $^{51}$

Alternative approaches to apportioning responsibility have been discussed under the UNFCCC. In 1997 Brazil made a proposal to equitably share the burden for mitigation,

\footnotetext{
47 ibid.

48 World Resources Institute, Contributions to Global Warming: 1900-1999, March 20 2008, <www.wri.org/map/contributions-to-global-warming > accessed 29 August 2013.

${ }^{49}$ Brown (n 36)193.

50 ibid.

51 These changes have now resulted in a more dynamic discussion about differentiation since the process of developing a new agreement in 2015. See for example the discussion in 'Summary of the Roundtable under Work stream 1, ADP1, part 2, Doha, Qatar, November-December 2012', Ad-Hoc Working Group on the Durban Platform for Enhanced Action, Note by Co-Chairs (7 February 2013), 3, http://unfccc.int/resource/docs/2012/adp1/eng/6infsum.pdf (accessed 1 May 2014)
} 
amongst developed countries, accounting for past contributions to global warming (henceforth 'Brazilian Proposal'). ${ }^{52}$ Emissions targets were based on historical responsibility, because a current emissions figure by a country did not reflect its 'actual' contribution to global warming. Similarly, a 'contraction and convergence' (henceforth 'C\&C') framework has been discussed whereby total global emissions reduced to meet a specific target, and the per capita emissions of industrialised and developing countries converge over a period of time, at an agreed rate and magnitude of contraction and convergence. ${ }^{53} \mathrm{C} \& \mathrm{C}$ applies principles of precaution and equity, principles identified as important in the UNFCCC but not defined. The C\&C approach has been used in many national climate change frameworks and could provide a basis for a future agreement. It provides for a flexible mechanism taking into account the increased emissions by certain developing countries. The principles behind this approach provide a framework, which is appropriately aware of the spatial and temporal dimensions of climate change. Further, it could be used to determine contribution to a future loss and damage fund.

Similarly, to apportion vulnerability we can draw upon the principles of historic polluter-pays, ability to pay, and priority. Despite the ubiquity of the impacts of climate change, overall vulnerability shows a geographical division between developed and developing states. On the question of large developing countries the approach necessary could look at both their physical vulnerability and economic ability to determine a claim. According to these two indices, a weighted system could incorporate their vulnerability in an approach consistent to the needs of distributive justice.

\subsubsection{Distributional Justice Within States}

Relatedly, inequality within countries obscures the lines between 'North' and 'South' or 'Annex' and 'non-Annex'. Take the case of India, a large developing country, very low in human development according to indices such as the Human Development Index and other development indicators. However, a report by Greenpeace India, Hiding Behind the Poor, highlights that the wealthy and middle classes of Indian society are consuming and emitting

\footnotetext{
${ }^{52}$ Brazil, Proposed Elements of a Protocol to the UNFCCC (FCCC/AGBM/1997/Misc.1/Add.3, 28 May 1997). (Brazil Proposal)

${ }^{53}$ Global Commons Institute, The Campaign for Contract \& Convergence (2008)

<www.gci.org.uk/kite/Carbon_Countdown.pdf> accessed 31 August 2013.
} 
at the same levels as those in developed countries. ${ }^{54}$ Thus, the high emitting wealthy and middle classes in India are able to essentially "hide behind the poor" with respect to international negotiations around climate change burdens. ${ }^{55}$ The report emphasises the extent to which emissions disparities exist between the rich and poor in developing countries.

In a quantitative analysis on climate justice, Baer creates a model of responsibility for climate change based on vulnerability and responsibility. ${ }^{56}$ Controversially, and conservatively, he weighs 'vulnerability' as equal for individuals in every country, regardless of wealth. ${ }^{57}$ His statistical analysis still concludes that a burden exists upon 'Annex' or 'developed' countries to compensate. This is important, because it gives credibility to the current division under the UNFCCC, even from a conservative analysis. Baer goes further looking at income inequality, emissions, and responsibility inside countries. He concludes, “The underlying principles of responsibility that are relevant for GHG liability are not based on nations except as a matter of pragmatism. The same distribution principles that apply between nations should apply within nations, with increased liability for those that are more responsible.”58

Though climate change is inter alia a class and distribution issue, whether the international stage can adequately respond to it is a difficult question and may detract or politicise negotiations too far from the main aim of the UNFCCC, the stabilisation of greenhouse gases. However, as a secondary feature, a loss and damage mechanism could at a minimum, recognise inequality inside states by incorporating principles and declarations urging that countries tackle issues of liability and responsibility within their jurisdiction. Efforts to ensure funds are allocated to those most vulnerable and liability is allocated to those individuals, classes, and communities who are most responsible are required. ${ }^{59}$ Section

\footnotetext{
${ }^{54}$ Greenpeace India, Hiding Behind the Poor (12 November 2007)

<www.greenpeace.org/india/Global/india/report/2007/11/hiding-behind-the-poor.pdf> accessed 31 August 2013.

55 Baskin (n 18) 7.

${ }^{56}$ P. Baer, 'Adaptation to Climate Change: Who Pays Whom,' in S. Gardiner et al. (eds) Climate Ethics: Essential Readings, (Oxford University Press, Oxford, 2010), pp. 247-263.

${ }^{57}$ Baer (n 56) 253.

${ }^{58}$ Baer (n 56) 258.

${ }^{59}$ Some countries, such as Bangladesh have set up funds to create internal loss and damage mechanisms, see for example: Abdullah Al Faruque and Mohammad Hafijul Islam Khan, 'Loss \& Damage Associated with Climate Change: The Legal and Institutional Context in Bangladesh' (Loss and Damage, June 2013,)<www.lossanddamage.net/download/6836.pdf> accessed 7 September 2013.
} 
3, discusses a range of liability regimes; such approaches could be used to internalise the costs of responsibility in the national context.

\subsubsection{Defining the Damage}

A key issue for a loss and damage mechanism is setting parameters for the damages that can qualify. As knowledge of loss and damage is an on-going process, it would be imperative to create a dynamic process of defining damages. In this respect, it is important to balance strong definitions to give claimants certainty, with flexibility to refine and benchmarks in line with growing scientific knowledge of loss and damage. ${ }^{60}$ At a conceptual level, the link between vulnerability and damages must be central to this exercise. The key area of difficulty will be capturing slow-onset events and non-economic vulnerability. Whereas pooled insurance-based mechanism could play a vital role in sudden onset events, it is less well equipped to deal with slow onset event, which require a much broader understanding of damages. ${ }^{61}$

In light of the difficulties in defining parameters of damage, Burkett proposes using the United Nations Compensation Commission (“UNCC”) as a blue print to resolve climaterelated claims. ${ }^{62}$ In the aftermath of the Iraq-Kuwait war, the UNCC was set up as a compensation and transitional justice mechanism. The UNCC included claims for environmental damage and the depletion of natural resources. Importantly, the UNCC facilitated claims for environmental damage that went beyond property damage, as well as including "other environmental damage" which included recovery for permanent damage for which restoration was infeasible. ${ }^{63}$ This provides a precedent for the international community as a mechanism for a broader, more holistic, definition of damage. Given the need for a dynamic process, a technical arm of a loss and damage mechanism would be ideally placed to drive this process. It would also be linked to the threshold of causation, which is discussed in more detail in section 4.2 .

\footnotetext{
${ }^{60}$ UNFCCC , 'A literature review on the topics in the context of thematic area 2 of the work programme on loss and damage: a range of approaches to address loss and damage associated with the adverse effects of climate change' (15 November 2012) UN Doc FCCC/SBI/2012/INF.14, 6.

${ }^{61}$ Maxine Burkett, 'Rehabilitation: A Proposal for a Climate Compensation Mechanism for Small Island States' (2015) 13 Santa Clara J. Int’l L. 81,100.

62 ibid.

63 ibid 111.
} 


\subsection{Transitional Justice}

Related to corrective justice, transitional justice is an evolving area of international law whose principles could be used by the climate regime for finding solutions to loss and damage. Transitional justice refers to processes and mechanisms used in countries and societies that are making transitions from violent conflict or large-scale human rights abuses. ${ }^{64}$ As such, it is usually understood as a set of mechanisms for achieving justice in periods of change, rather than a substantive concept of justice in its own right. ${ }^{65}$ However, its models and ethos are useful in trying to frame a just mechanism to address loss and damage.

Reparation actions are a form of transitional justice. The UNCC, discussed above, is an example of reparation actions for environmental harms. The ethos of reparations is based on legal principles that require perpetrators to return wronged individuals to the status quo ante, or if not, possibly compensate victims for their injuries. ${ }^{66}$ Importantly, they are both backward and forward looking in nature. Reparations seek to identify and compensate for an exact past harm. Yet, they are forward-looking in that they recognise that the past harm can have a current and continuing effect. Rather than an exact calculation of monetary payment based on those current harms, reparations seek to improve lives into the future. ${ }^{67}$

Scholars have recently proposed mechanisms to widen transitional justice mechanisms. Blum and Lockwood argue that there is no moral or ethical reason why reparations cannot be expanded to compensate victims of natural disasters and other causes of human suffering. ${ }^{68}$ The unique moral and scale issues of climate change demand strategies which are 'outside the box'. Transitional justice has often been an area of law that has had the flexibility of adopting new institutional mechanisms outside of traditional legal structures. Jamieson points out that climate change discussions often lack the voice of morality, specifically care, empathy, responsibility, and duty; rather, they focus more on science,

\footnotetext{
${ }^{64}$ Joy Hyvarinen, 'Climate Change in the Dock: Rethinking the role of international law' (Climate Home, 12 March 2013) <www.rtcc.org/2013/06/06/why-a-radical-legal-landscape-is-needed-to-ensure-climate-justice/> accessed 9 August 2013.

${ }^{65}$ Gabriella Blum and Natalie J. Lockwood, 'Earthquakes and Wars: The Logic of International Reparations' (2012) Harvard Public Law Working Paper No. 12-30, 28 http://papers.ssrn.com/sol3/papers.cfm?abstract_id=2096811 accessed 8 August 2013.

${ }^{66}$ Maxine Burkett, 'Climate Reparations’ (2013) 10(2) Melbourne Journal of International Law, 13

<www.law.unimelb.edu.au/files/dmfile/downloadfe121.pdf> accessed 4 April 2014.

67 ibid 14.

${ }^{68}$ Blum and Lockwood (n 65).
} 
economics, and technology. ${ }^{69}$ Transitional justice has often been more normative, holistic, and forward looking. Given its ethos, it could provide the comprehensive approach necessary to address the injustice faced by the climate vulnerable. ${ }^{70}$

Transitional justice also posits that to centre the moral claim, an admission of liability and responsibility is an important part of the process. One cannot expect admission to come easily. However, the allocation of responsibility and liability in the climate regime itself would go a long way in centring the moral claim. As a corollary to admission, transitional justice often bases its processes on bringing out the voices of victims. For climate change loss and damage, the inclusion of civil society is a vital part of this process. Value should be given not only to NGOs, but also collectives and unions directly representing the voices of vulnerable groups. Hearing the impacts of climate change upon farmers, peasants, indigenous people, women and other extremely vulnerable and marginalised groups are examples of this process. This would further justice and legitimacy in addressing the impacts of loss and damage.

\subsection{Summary}

To recap, there is an ethical imperative for an international loss and damage mechanism, based on the concept of corrective justice. Environmental justice principles assist in obliging historically polluting countries to hold principal responsibility for contributing to compensation. However, current and future emissions need to be taken into account when apportioning responsibility. Any claim to vulnerability must address historic and current emissions, as well as actual physical vulnerability and economic 'ability to pay' (for costs of adaptation or addressing damage). It has been argued that a state-centric approach must be maintained for pragmatic reasons and that inequalities inside states need to be emphasised by an international mechanism. Defining loss and damage is an on-going process, however at a minimum it must link to vulnerability and include a broader definition of damage to ensure that the complexities of climate impacts are captured. Furthermore, transitional justice frameworks are useful models to deal with the gravity of climate change issues and centring the voice of morality, in addition to being both backward and forward looking in assisting parties to move past the harm that has occurred.

\footnotetext{
${ }^{69}$ Dale Jamieson, 'The Moral and Political Challenges of Climate Change' (unpublished manuscript, 26 February 2007) <www.colorado.edu/GeolSci/courses/GEOL3520/Jamieson-paper\%20Climate\%20Ethics.pdf> accessed 6 September 2013.

${ }^{70}$ Burkett (n 66) 13.
} 


\section{The Legal Underpinning of a Loss and Damage Mechanism}

Legal parameters are important in ascertaining who is responsible for climate change damages, when such responsibility can be attributed, and how burden sharing operates. Recent scholarship has pointed out that there is a prima facie case for vulnerable countries to bring a legal claim against developed and industrialised countries for climate change damages. ${ }^{71}$ In 2011, Palau announced plans to seek an advisory opinion from the International Court of Justice ('ICJ') on the obligations and responsibilities of states under international law to avoid transboundary harm caused by GHG emissions. ${ }^{72}$ Although an advisory opinion would be non-binding, it would mark a potential turning point for the climate regime and formally define states' obligations and responsibilities with respect to emissions under international law.

An international loss and damage mechanism will be a political decision, rather than a judicial one regarding compensation. As the Warsaw Mechanism is through the UNFCCC then the principles of international law are still vital in creating a consistent and coherent mechanism. This consistency would also be in line with the 2012 'Declaration on the Rule of Law at the National and International Levels', adopted by the General Assembly, which reaffirmed a commitment of the international community to the international rule of law as a way to respond to challenges of collective concern. ${ }^{73}$

\subsection{Who Has to Pay: The Law of State Responsibility}

Establishing legal responsibility is both important in holding states liable for climate change damage and as a legal precursor to a loss and damage mechanism. Without legal responsibility or liability, it is difficult to hold states to account and develop a strong regime. As will be discussed later, one of the key issues with funding is that liability has never been established for climate change.

\footnotetext{
${ }^{71}$ Christina Voigt, 'State Responsibility For Climate Change Damages' (2008) 77 Nordic Journal of International Law 1.

${ }^{72}$ Douglas Kysar, 'Climate Change and the International Court of Justice’ (2013) Yale University Working Paper Series < papers.ssrn.com/sol3/papers.cfm?abstract_id=2309943> accessed 3 September 2013.

${ }^{73}$ UNGA Res 67/1 (2012).
} 
The law of state responsibility is primarily governed through the International Law Commission's (henceforth 'ILC') Draft Articles on Responsibility of States for Internationally Wrongful Acts (henceforth 'DASR'). The DASR do not create law; however, they are a codified restatement of the existing law of state responsibility. ${ }^{74}$ Under Article 1 of the DASR, state responsibility for an action is triggered when there is a breach of an international legal obligation. Such an obligation can be established by treaty, by a rule of customary international law, or under general principles of international law. ${ }^{75}$

The DASR is not specific to environmental damage. As such there are no specific environmental treaties or standards that establish a threshold for environmental damage that triggers liability and allows for claims to be brought. ${ }^{76}$ The need for effective liability and state responsibility for environmental damage is stressed by soft law instruments. ${ }^{77}$ International case law, state practice, and legal scholarship have seen the slow development of the law of state responsibility for environmental damage. ${ }^{78}$

Legal consequences arise when an internationally wrongful act has been committed. The general system to establish state responsibility under the DASR can be summarised as follows:

i. There is a breach of an international obligation;

ii. The breach is attributable to a State;

iii. Once the breach is established, another Sate can demand cessation of the wrongful act (re-instatement of lawful behaviour and/or reparation, including compensation if there is injury).

These criteria to test the law of state responsibility are now considered in greater depth with reference to climate change loss and damage.

\footnotetext{
${ }^{74}$ Roda Verheyen, Climate Change Damage And International Law (M Nijhoff 2005) 234.

${ }^{75}$ P. Sands and J. Peel, Principles of International Environmental Law, $3^{\text {rd }}$ ed. (Cambridge University Press, Cambridge, 2012) p. 705.

76 ibid 708.

${ }^{77}$ Principle 13, Rio Declaration (n 35); and Principle 22, Stockholm Declaration on the United Nations Conference on the Human Environment (1972) 11 ILM 1416.

${ }^{78}$ For example see case law such as: Case concerning Gabcikovo-Nagymaros Project (Hungary $v$ Slovakia) [1997] ICJ Rep 7 ; Legality of the Threat or Use of Nuclear Weapons (Advisory Opinion) [1996] ICJ Rep 241; Trail Smelter Arbitration (United States v Canada), Award of 1941, III RIA 1911.
} 
4.1.1 Has an international obligation been breached?

Under Article 12 of the DASR, a State commits a wrongful act when its conduct does not conform with an international obligation. ${ }^{79}$ State responsibility under the DASR only applies when there is a breach of an international obligation under treaty or custom.

\subsubsection{Treaty Law}

The UNFCCC is the primary treaty regulating GHG emissions and is the source of inquiry into an obligation, which can invoke state responsibility. ${ }^{80}$ In general, the UNFCCC has tried to avoid the question of state responsibility, liability, and damage. This is consistent with broader environmental law, where states have been reluctant to use the mechanism of state responsibility to address the consequences of environmental damage and reflects an unwillingness to agree to something that may eventually find them liable. ${ }^{81}$ In response, some states have made a declaration that signing the Convention was not renunciation rights under international law concerning responsibility for the adverse effects of climate change. ${ }^{82}$

Article 2 of the UNFCCC states the ultimate objective of the Convention is the "stabilization of greenhouse gas concentrations in the atmosphere at a level that would prevent dangerous anthropogenic interference with the climate system.” The article assumes that humans interfere with the climate system and recognises that human activity impacts GHG concentrations. The preamble of the Convention gives further context to this objective noting historical and current emissions levels by countries. ${ }^{83}$ Voigt argues that a 'duty of prevention' exists under Article 2 for Parties to stabilise emissions. ${ }^{84}$ Though the provision identifies the overall objective, Article 2 is part of an international treaty and therefore must be analysed in the context of international law, rather than simply a political declaration. Under the Vienna

\footnotetext{
79 Verheyen (n 74) 235,

${ }^{80}$ Other treaties are applicable for climate change damages, such as UNCLOS and the Convention on Biological Diversity, see for example: Douglas Kysar (n 72) 19-27.

${ }^{81}$ Cullet (n 21) 107.

${ }^{82}$ Verheyen (n 74) 236.

${ }^{83}$ Recital 2 and 3 UNFCCC. Preambular paragraphs provide interpretive and contextual guidance to substantive articles in a treaty see Article 31 of the Vienna Convention on the Law of Treaties (opened for signature 24 May 1969, entered into force 27 January 1980) 1155 UNTS 331.

${ }^{84}$ C. Voigt (n 71) 5.
} 
Convention of the Law of Treaties ${ }^{85}$ ("VCLT"), Article 2 must be given its ordinary meaning (Article $31.1 \mathrm{VCLT}$ ), that there is an obligation to prevent dangerous anthropogenic interference with the climate system. In addition, Parties must refrain from acts that would defeat the purpose of the treaty (Article 18 VCLT) ${ }^{86}$ The Principles of the UNFCCC under Article 3 reaffirm an emphasis to prevent damage and highlights the precautionary principle of international environmental law that the "lack of full scientific certainty should not be used as a reason for postponing such measures." 87

Under Article 4.2 of the Convention, Annex I Parties commit themselves to adopting national policies and implementing corresponding measures towards the mitigation of climate change by limiting anthropogenic emissions of GHGs and protecting sinks. As Article 4.2 was heavily debated in the Convention's negotiations, it led to a weak provision. Bodansky has stated that Article 4.2 is "highly ambiguous" and "heavily qualified", making it questionable whether the Convention creates a legally binding target at all. ${ }^{88}$ The 'Berlin Mandate' reaffirmed the weakness of this provision and lead to the Kyoto Protocol ${ }^{89}$, which set more robust targets and timetables. ${ }^{90}$ But despite its weaknesses at putting forward a quantifiable, legally binding target, Article 4.2 can be interpreted in light of Article 18 of the VCLT as putting forward an 'obligation of conduct' to reverse ever increasing GHG emissions. $^{91}$

These relatively modest provisions render it difficult to establish an enforceable duty on states to reduce GHG emissions. Some legal scholars have argued that there are enforceable minimum obligations under the Convention. Voigt argues that Article 2 and 4.2 place duties on Annex I Parties to, at a minimum, not defeat the

\footnotetext{
${ }^{85}$ Vienna Convention on the Law of Treaties (n 83).

${ }^{86}$ Verheyen (n 74) 55-56.

${ }^{87}$ UNFCCC (n 2) article 3.3.

${ }^{88}$ Daniel Bodansky, 'The U.N. Framework Convention on Climate Change: A Commentary’ (1993) 18 Yale Journal of International Law 516.

${ }^{89}$ Kyoto Protocol to the United Nations Framework Convention on Climate Change (adopted 11 December 1997, entered into force 16 February 2005) 2303 UNTS 148.

${ }^{90}$ UNFCCC, Decision 1/CP.1, 'The Berlin Mandate: Review of the adequacy of Article 4, paragraph 2 (a) and (b), of the Convention, including proposals related to a protocol and decisions on follow-up' (6 June 1995) FCCC/CP/1995/7/Add.1.

${ }^{91}$ Voigt (n 71) 6.
} 
objective, consistent with Article 31 of the VCLT. ${ }^{92}$ Hence, a State Party could be breaching the Convention if it has continued to increase emissions since the ratification of the UNFCCC at rates that may lead to dangerous climate change. Further, Voigt states that adaptation funding is not voluntary, but a "substantive obligation on all Parties with a view to reducing future climate change damage.”93 Tol and Verheyen argue that countries that do not meet Kyoto Protocol targets could be responsible, as they would be breaching international law. ${ }^{94}$ In addition, Verheyen has argued that Annex I countries that do not make 'real efforts' to meet these targets breach both the UNFCCC and the Kyoto Protocol. ${ }^{95}$ By 'real efforts' she refers to compliance with co-operation duties, finding adequate regulatory solutions to reach the objective of the UNFCCC, and enacting suitable legislation based on scientific findings of absolute emissions levels. ${ }^{96}$

Overall, state responsibility for climate change damages based on treaty law, through the UNFCCC, remains uncertain given the relatively weak obligations under the Convention. Though it is not impossible to conceive of a breach under the UNFCCC, it remains a controversial topic without much consensus.

\subsubsection{Customary International Law}

A breach of an obligation under customary international law can also trigger state responsibility. ${ }^{97}$ The no-harm rule is a widely recognised principle of customary international law and is applicable in the context of climate change. Under the noharm rule, states have an obligation to not damage the environment of other states and areas beyond its jurisdiction. ${ }^{98}$ The basis for this rule is found through case law, state practice, and other legal instruments.

The legal precedent for the no-harm rule stems from the Trail Smelters case, where a Canadian smelter's emissions had caused air pollution damage across the

\footnotetext{
92 ibid 7.

93 ibid 6.

${ }^{94}$ Tol and Verheyen (n 5) 1115.

${ }^{95}$ Verheyen (n 74) 283.

96 ibid.

${ }^{97}$ Voigt (n 71) 7.

98 ibid.
} 
border into the United States. ${ }^{99}$ The no-harm principle is codified under Principle 21 of the Stockholm Declaration and Principle 2 of the Rio Declaration, where all states have the "responsibility to ensure that activities within their jurisdiction or control do not cause damage to the environment of other States or areas beyond the limits of national jurisdiction”. The Convention on Biological Diversity (henceforth 'CBD') (Article 3) and the United Nations Convention on the Law of the Sea (henceforth 'UNCLOS') (Article 194, para 2) and other international texts include the no-harm rule. ${ }^{100}$ Additionally, the rule has been given authority by the ICJ in advisory opinions and judgements. ${ }^{101}$ In the context of climate change, the no-harm rule is importantly referred to in Recital 8 of the UNFCCC preamble. ${ }^{102}$

No threshold for harm as such has been agreed upon for the environment to trigger a liability claim. Whilst all pollution or human activity having adverse effects might give rise to environmental damage, it is unlikely that all environmental damage results in state liability. ${ }^{103}$ State practice and international legal instruments have indicated that 'significant' damage must have occurred before the no-harm principle has been breached and state responsibility can be invoked. In Trail Smelters, it was held that a 'serious consequence’ was necessary. Similarly, the 2001 ILC Draft Principles on Prevention of Transboundary Harm seeks to prevent 'significant' harm. ${ }^{104}$ In the commentary to the 2001 Draft Principles, the ILC observed that 'significant' can be defined as "something more than detectable but not at the level of serious or substantial”, ${ }^{105}$ Thus, not all types of damage must be prevented, but a de minimis threshold exists for transboundary environmental damage. ${ }^{106}$

\footnotetext{
99 Trail Smelter Arbitration (United States v Canada) (n 78).

${ }^{100}$ Rio Declaration, Principle 2; Convention on Biological Diversity (adopted 5 June 1992, entered into force 29 December 1993) 1760 UNTS 79 (CBD) art 3; United Nations Convention on the Law of the Sea (adopted 10 December 1982, entered into force 16 November 1994) 1833 UNTS 3 (UNCLOS) art 194(2).

${ }^{101}$ Legality of the Threat or Use of Nuclear Weapons (Advisory Opinion) [1996] ICJ Rep 226; Case concerning Gabcikovo-Nagymaros Project (Hungary v Slovakia) [1997] ICJ Rep 7 41; Case concerning Pulp Mills on the River Uruguay (Argentina v Uruguay) [2010] ICJ Repo 1, 38

${ }^{102}$ Looking ahead it is hoped that if Palau goes ahead with an ICJ advisory opinion request, the ICJ formalises this rule in the context of climate change.

103 Sands and Peel (n 75) 708.

${ }^{104}$ International Law Commission, 'Draft Principles on Allocation of Loss in the Case of

Transboundary Harm Arising out of Hazardous Activities, Report of the International Law Commission on the Work of its 58 ${ }^{\text {th }}$ Session (2006) A/56/10, 2006.

${ }^{105}$ International Law Commission, 'Draft Articles on the Prevention of Transboundary Harm from Hazardous Activities with commentaries' (2001) Yearbook of the International Law Commission, <legal.un.org/ilc/texts/instruments/english/commentaries/9_7_2001.pdf> accessed 1 August 2013. ${ }^{106}$ Voigt (n 71) 9.
} 
The IPCC Fourth Assessment Report is fairly clear that the impacts of climate change will result in significant damages to the environment, human health, and property. Therefore, climate change injuries and damages are meeting, at least, a de minimis threshold required for a breach of the no-harm rule. Under international law, if a state is found to violate international legal principles such as the no-harm rule, then it is obliged to compensate affected states for the damage caused, either directly or indirectly. ${ }^{107}$

\subsection{Can responsibility be attributable to the state?}

State responsibility for climate change damages requires that state behaviour can be identified or that the actions of private persons can be attributed to the state. ${ }^{108}$ As a large proportion of emissions are by private corporations and citizens rather than the state itself, the concept of 'due diligence', as a standard of care for government authorities can be applied to invoke state responsibility for climate change damages. ${ }^{109}$ Due diligence, under international law, is said to comprise at least the following elements ${ }^{110}$ :

i. Opportunity to act or prevent;

ii. Foreseeability or knowledge that a certain activity could lead to transboundary damage; and

iii. Proportionality in the choice of measures required to prevent harm or to minimise risk.

The ILC has noted that acting with due diligence requires a state to formulate policies designed to prevent "significant transboundary harm” or to "minimize the risk thereof" and implement these policies. ${ }^{111}$ Therefore, a state may be liable for resulting harm if, despite such foreseeability, proportionate policy measure were not taken and significant harm was caused.

\footnotetext{
${ }^{107}$ Chorzow Factory [1927] PCIJ Rep 7.

108 Voigt (n 71) 9.

109 ibid. ; Legal Response Initiative, 'No Harm Rule and Climate Change’ (LRI Briefing Papers, 24

July 2012) <www.legalresponseinitiative.org/download/BP42E\%20-\%20Briefing\%20Paper\%20\%20No\%20Harm\%20Rule\%20and\%20Climate\%20Change\%20(24\%20July\%202012).pdf> accessed 14 August 2013.

${ }^{110}$ Legal Response Initiative, ibid.

${ }^{111}$ ICL, 'Report of the International Law Commission at Its 53 ${ }^{\text {rd }}$ Session' (2001) UN Doc.A/56/10, Article 3, p.393.
} 
In real terms, the link between GHG emissions and the potential impacts of climate change have been known since at least the early 1990s when the UNFCCC was negotiated. According to Voigt, acting with due diligence requires states to keep abreast with scientific development and take effective mitigation measures based on the best available technologies. ${ }^{112}$ It also requires states to substantially reduce GHG emissions, effectively obliging a State to "do the best it can in reducing the risks that result from climate change”. ${ }^{113}$ At a minimum, developed countries, as those with the opportunity to act and the highest emissions, have an obligation to limit emissions as a proportionate response - even if this was at the expense of economic growth. However, despite opportunities and foreseeability, mitigation action has been inadequate.

For a state to be responsible for a breach of an international obligation, there also needs to be a causal nexus between the actions of a state and damage. Climate change presents a variety of impacts caused by a variety of actors and a variety of actions. By its nature it is impossible to attribute emissions of a specific country to specific damage. ${ }^{114}$ This presents a difficulty to reconcile with traditional 'but-for' or 'specific causation' that requires proof that a specific activity links directly to a particular injury. However alternative theories of causation, or a combination of theories opens up a possibility to optimise fairness for parties. Tol and Verheyen have posited that general causation can be used as a basis for climate change damages. ${ }^{115}$ General causation refers to a causal link between an activity and the general outcome. In this case, a proof that GHG emissions lead to climate change, which then leads to impacts on ecosystems, such as air temperature rises, sea level rises and so on. ${ }^{116}$ Duffy, has advocated for a probabilistic causation test, where a claimant brings scientific evidence of cause of damage and the evidence is allowed to stand even if it shows less than 50\% contribution to the risk of harm (a limitation under traditional causation tests). ${ }^{117}$ The evidence is then assessed according to whether it is more likely than not accurate and liability is apportioned linking to the

\footnotetext{
112 Voigt (n 71) 11-13.

113 ibid.

114 ibid 15.

115 Tol and Verheyen (n 5) 1115.

116 ibid.

${ }^{117}$ Michael Duffy, 'Climate Change Causation: Harmonizing Tort Law and Scientific Probability' (2009) 28 Temp. J. Sci. Tech. \& Envtl. L. 185.
} 
percentage by which anthropogenic influences contributes to the risk of harm and divided based on share of greenhouse gases. ${ }^{118}$ There are many policy reasons for allowing such alternative, expanded, or hybrid tests of causation, but most notable that the victim should not be left without a remedy just because multiple causes or defendants cause harm. ${ }^{119}$ Such tests are often used in complex torts cases, involving multiple defendants or multiple causes. ${ }^{120}$

Indeed, concern about not being able to use traditional specific causation has been used by countries to argue against an international loss and damage mechanism. ${ }^{121}$ However, international law does not specify any formula for determining causation and thus tests of causation that are more suitable from a justice point of view, such as a general causation test, can be used. There is almost universal international scientific consensus today that anthropogenic emissions of GHGs have caused changes in the radiative forcing balance in the atmosphere causing climate change. ${ }^{122}$ The IPCC has predicted that regional changes in temperatures have already significantly affected many physical and biological systems. ${ }^{123}$ Furthermore, a loss and damage mechanism at the international level, though based on principles of international law, is not as tightly constrained by the judicial limitations of climate change litigation and case law. General causation (or other hybrid tests of causation) provides a legal underpinning to attribute climate damages upon states.

In section 2, equitable burden-sharing options for responsibility were discussed. Attribution could be apportioned under burden-sharing mechanisms using the principles of international environmental law such as historic polluter-pays and CBDRRC. ${ }^{124}$

\subsection{An international liability mechanism}

\footnotetext{
118 ibid 189.

119 ibid.

120 Several of these tests are discussed in M.Duffy (n 117).

${ }^{121}$ United States of America, The Role of the Convention in Addressing Loss and Damage Associated with the Adverse Effects of Climate Change (16 November 2012)

<unfccc.int/files/documentation/submissions_from_parties/application/pdf/us.pdf> accessed 1 August 2013.

122 Tol and Verheyen (n 5) 1118.

${ }^{123}$ Fourth Assessment Report (n 1).

${ }^{124}$ Such as that envisioned by the 'Brazilian Proposal' (n 52).
} 
The above discussions have illustrated that state responsibility is applicable for climate change loss and damage. Under Article 31 DASR, there is a duty to make “full reparation for the injury caused by the internationally wrongful act”. Under Principle 13 of the Rio Declaration, States should "cooperate in an expeditious and more determined manner to develop further international law regarding liability and compensation for adverse effects of environmental damage”.

As previously discussed, the UNFCCC does not mention liability or state responsibility, which continues to remain a regulatory gap in the regime. Positivist legal theory, such as the works of Austin and Kelsen, holds that sanctions are a key element to legal rules. ${ }^{125}$ As Cullet states, "without liability and redress or state responsibility rules, the climate change regime will remain largely ineffective from the point of view of people and countries suffering from its on-going impacts.”126 However, environmental law does provide for liability in other sectors, which can provide models and lessons for a loss and damage mechanism.

Existing environmental liability mechanisms fall into two broad categories: state liability and civil liability. The former is liability found under international law and imposes liability on the state for ensuing damage. The rules of state liability for environmental damage remain fairly underdeveloped and addressed only by a small number of treaties. ${ }^{127}$ One example is the Space Liability Convention in 1972, which introduces a clear rule of state liability for damage from State Parties carrying out space programmes. ${ }^{128}$ However, one of the major issues for state liability mechanisms for environmental damage is that states are reluctant to put in place rules regarding state liability or foster principles that might be applied against them. ${ }^{129}$

More common are liability regimes, which impose civil liability on third party private and public actors for environmental damage. ${ }^{130}$ Some of these include the

\footnotetext{
125 Brian Bix, Jurisprudence: Theory and Context, (Sweet and Maxwell 2006) 55-63.

${ }^{126}$ Cullet (n 21) 116.

127 Sands and Peel (n 75) 727.

128 ibid 730.

129 Cullet (n 21) 107.

130 Joanne Linnerooth-Bayer, M.J. Mace, and Roda Verheyen, 'Insurance-Related Actions and Risk Assessment in the Context of the UNFCCC’ (Background paper for UNFCCC workshops, May 2003) <unfccc.int/files/meetings/workshops/other_meetings/application/pdf/background.pdf> accessed 31 August 2013.
} 
Vienna Convention on Civil Liability for Nuclear Damage, ${ }^{131}$ the Basel Convention on the Control of Transboundary Movements of Hazardous Wastes and their Disposal $^{132}$, and the International Convention on Civil Liability for Oil Pollution Damage $1992^{133}$ (henceforth 'CLC').

Despite the variety of subject matter, most civil liability regimes follow similar models. This includes defining the activities covered and what damage entails, channelling liability, establishing a standard of care, providing liability amounts, allowing exonerations, requiring adequate financial security, and identifying a tribunal or court to hear claims. ${ }^{134}$ Much of this framework can be drawn upon for a climate change loss and damage mechanism. However, it is worth expanding on three important issues, namely defining damage (which in turn affects what is compensated), funding liability regimes, and measuring compensation.

Some treaties, such as UNCLOS, do not define damage nor establish a measure of compensation. Rather a number of articles in UNCLOS guide the discussion. Additionally UNCLOS benefit from a tribunal type forum for claims to be defined and measured. ${ }^{135}$ Damage in the Space Liability Convention focuses on human health and loss or damage to property. ${ }^{136}$ Sands and Peel argue that although the definition does not refer to environmental harm, it can be interpreted to allow compensation for claims for the 'property of states' that are environmental assets or other natural resources. ${ }^{137}$ Civil liability regimes, such as the CLC, focus on 'pollution damage’ defined as 'loss or damage’ caused outside the ship through 'contamination'. 138

\footnotetext{
${ }^{131}$ Convention on Civil Liability for Nuclear Damage (adopted 21 May 1963, entered into force 12 November 1997) 1063 UNTS 265. .

132 Protocol on Liability and Compensation for Damage Resulting from Transboundary Movements of Hazardous Wastes and their Disposal (adopted 10 December 1999) U.N. Doc. UNEP/CHW.5/29, 10 December 1999).

133 Protocol to amend the 1971 International Convention on the Establishment of an International Fund for Compensation for Oil Pollution Damage (adopted 27 November 1992, entered into force 30 May 1996) 1953 UNTS 330. (CLC)

134 Sands and Peel (n 75) 738.

135 ibid 730.

${ }^{136}$ Convention on International Liability for Damage Caused by Space Objects (adopted 29 November 1971, entered into force 1 September 1972) 961 UNTS 187, art 1.

137 Sands and Peel (n 75) 728.

138 ibid.
} 
The Lugano Convention is one exception to most civil liability regimes as it is ambitious in expanding the reach of liability from sectoral to regional. ${ }^{139}$ The overall objective is to ensure adequate compensation for damage resulting from activities dangerous to the environment and also includes the costs of preventative measures and any loss or damage caused by preventive measures. ${ }^{140}$ However, the Lugano Convention's political feasibility is uncertain, as it has not been ratified by any State Parties and it is doubtful whether it ever enters into force.

The CLC provides a good example of a funding mechanism with pool funding. Under the CLC, liability is established for the owner of a ship for pollution damage, or 'loss or damage outside a ship carrying oil by contamination' ${ }^{141}$ The regime operates under strict liability, and there are caps to liability depending on guilt of parties. Attached to the CLC is the 1992 Fund Convention, which establishes an International Oil Pollution Compensation Fund (henceforth 'IOPC Fund'); the IOPC provides compensation for pollution damage that is inadequately compensated through the CLC. ${ }^{142}$ Annual contributions are made into the IOPC Fund by each party carrying above a certain level of oil into ports.

This type of fund and liability mechanism acts as a form of 'pre-disaster risk hedging' purchased by each state. ${ }^{143}$ Participation in the regime by a state reduces uncertainty (risk), which might otherwise be the case. It prevents states from having to act as unwilling insurers of their own and their citizens' losses. This is particularly relevant when adequate compensation cannot be obtained from responsible parties, either because operator liabilities have caused bankruptcy or causation cannot be determined. ${ }^{144}$ It also implements the polluter-pays principle, by shifting the costs of harm directly on to the person or entity most responsible for the activity causing damage. Only if operator liability is insufficient does a mechanism for a state or a

\footnotetext{
${ }^{139}$ Convention on Civil Liability for Damage Resulting from Activities Dangerous to the Environment (Lugano Convention).

140 ibid Article 2; also see P. Cullet (n 21) 114.

${ }^{141}$ CLC (n 131) art 1.

${ }^{142}$ CLC (n 131) art 3.

${ }^{143}$ Verheyen (n 74) 342.

144 ibid.
} 
global collective loss sharing arrangement apply to address uncompensated damage. ${ }^{145}$

Though much can be drawn upon from existing liability regimes, applying the frameworks of current environmental liability regimes to climate change does have certain shortcomings and challenges.

First, liability mechanisms existing today are mainly for acts of pollution or injury to property caused by accidents. Damage from the impacts of anthropogenic climate change are caused by conduct, which is 'normal', though cumulatively cause negative environmental effects. This is not only conceptually different, but in practical terms, there is no one particular operator's conduct that can be blamed (the problem of attribution). However, attribution should not be an impediment, as flexibility under a pooled or joint liability systems could provide an answer. Poolfunding mechanisms are particularly useful to apportion responsibility adequately and draw funds from a large number of parties. Further, normal activity of GHG emissions over a certain point could be used as signalling liability. Alternatively, as the 1991 AOSIS Proposal put forward, if sea levels reach a certain threshold, some form of responsibly is invoked for a certain group of countries and any pooled fund then pays compensation for damage. ${ }^{146}$

Second, defining damage is more complex in a climate change context. Current environmental liability regimes, with the exception the Lugano Convention, are fairly restricted in scope. Definitions of damage are limited to environmental damage or direct property damage from contamination. However, climate change poses unique difficulties, such as slow-onset changes and damages beyond environmental and property damage. It is important to realise a definition of loss and damage, which is both inclusive and politically feasible. This will undoubtedly be one of the most difficult tasks for the UNFCCC bodies and State Parties.

Finally, current environmental liability regimes offer ex-post damages that can be quantified through existing mechanisms of measuring loss and damage. Ex-post

\footnotetext{
145 Linnerooth-Bayer, Mace and Verheyen (n 130) 31.

146 Verheyen (n 74) 343.
} 
responses, though beneficial after a major disaster, have a disadvantage in that they do not prevent fatalities or damage and could also be fairly cumbersome to respond to damages. Ex-ante measures, such as insurance, have the advantage of being relatively fast and reliable, with payouts to beneficiaries being fairly certain. ${ }^{147}$ Neither ex-ante nor ex-post mechanisms can fully respond to the multitude or risks that climate change damages entails. A proposal put forward by AOSIS in 2008 for instance has proposed a dual nature alternative (with compensation and insurance pillars) to try an overcome this.

\subsection{Summary}

The ethical positions discussed in section 2 are supported by international law, through the law of state responsibility, which invokes liability where there has been a breach of an international obligation. Though there are significant gaps in invoking state responsibility through a breach of a treaty provision, there is a stronger legal imperative through a breach of the no-harm rule under customary international law. By invoking alternative or hybrid tests of causation and due diligence, attribution can be apportioned to State Parties.

Liability mechanisms have at least a political imperative under international environmental law. Existing liability regimes are largely sector specific and deal with climate change inadequately. This issue remains a large regulatory gap in the climate change regime and are an imperative to a working loss and damage mechanism. Existing liability regimes, such as those for oil pollution, can be used more generally to show that 'pooled funds' and international liability mechanisms, in general, do have working precedents. Existing regimes also provide a general framework for use; yet, they need to incorporate the unique characteristics of climate change, such as slow onset events, and work with risk management mechanisms (insurance)

\footnotetext{
${ }^{147}$ Grantham Research Institute on Climate Change and the Environment \& The Centre for Climate Change Economics and Policy, 'Submission on views and information on what should be included in the Work Programme to consider approaches to address Loss and Damage' (21 February 2011) <unfccc.int/resource/docs/2011/smsn/ngo/251.pdf> accessed 31 August 2013.
} 


\section{A framework for implementation}

In light of the discussions in section 2 and 3, the following framework is suggested to create a 'just regime' to address loss and damage. That an international loss and damage mechanism:

i. Defines and delineates 'responsible parties', and 'victims';

ii. Prioritises the needs of the 'most vulnerable' and is inclusive to the voices of the most vulnerable;

iii. Operates as a pool fund to ensure contributions which signify the common responsibility of nations;

iv. Ensures flexibility in a definition of 'damage', which incorporates the property, the environmental, and the human costs of damage;

v. Considers prior historic emissions, as well as current and future emissions;

vi. Emphasises a transitional justice ethos of recognition of responsibility, as well as centring the moral question of loss and damage; and

vii. Works effectively with other policy to mitigate greenhouse gases and promote sustainable development.

This framework will now be used to closely analyse the UNFCCC and see whether the UNFCCC is able to provide for a loss and damage mechanism, as well as suggesting 'ways forward'. Three pertinent questions are discussed below.

1. Does the UNFCCC effectively identify parties to damage claims and govern

2. How is finance and funding dealt with under the UNFCCC?

3. Does the UNFCCC adequately centre moral questions of loss and damage?

\subsection{Identifying Parties and Governing a Mechanism}

The preceding sections have shown that a loss and damage mechanism would have to clearly identify parties who are responsible for damage and those who are victims or potential claimants for compensation. There is an ethical imperative to compensate those who are most vulnerable and a legal imperative under customary international law to compensate those who are harmed. 
Arguably, the UNFCCC identifies both responsible parties and vulnerable parties, without directly applying a corrective justice or liability framework. Article 4.3, 4.4, and 4.5 put forward obligations on Annex II Parties to finance and support developing country adaptation measures. Under Article 4.4 developed countries are to assist developing countries in coping with the adverse effects of climate change. Sands and Peel state that Article 4.4 represents an "implicit acceptance” by developed country parties of responsibility for causing climate change. ${ }^{148}$

Articles 4.8 and 4.9 contain commitments applicable to all Parties to give special consideration to particular groups of developing country Parties. Under Article 4.8, nine groups and types of countries are listed that must be specifically accounted for, eight of which refer to the particular vulnerability of certain countries to the impacts of climate change. ${ }^{149}$ It specifies that in their implementation of the Convention all Parties shall give 'full consideration to what actions are necessary under the Convention, including actions related to funding, insurance, and transfer of technology to meet specific needs and concerns’ of such developing country parties arising from the adverse effects of climate change, and that the COP 'may take actions, as appropriate, with respect to this paragraph.' Through broad, Article 4.8 can be interpreted as including both financial and technical needs for damage prevention (adaptation) along with the associated costs of residual climate change damage (loss and damage).

These provisions are not strong enough to justify a loss and damage mechanism themselves, but do provide a footing for discussions and negotiations. The COP and the UNFCCC do not define which countries are particularly vulnerable, nor set out criteria to establish this. Based on a variety of information, such as IPCCC Reports and initial national communications, the COP has instead highlighted the need to meet the adaptation needs of two particular groups of countries: LDCs and SIDS. A loss and damage mechanism would need to specify responsible parties, as

\footnotetext{
148 Sands and Peel (n 75) 282.

${ }^{149}$ Article 4.8 does also include a provision for countries that will suffer economic hardships arising from mitigation efforts (essentially oil producing countries). This is politically contentious and problematic overall for the regime.
} 
well as countries that are able to claim compensation in a clearer way, to ensure there is a robust mechanism in place.

A major issue in recent debates on loss and damage under the UNFCCC has been the membership of the interim Executive Committee, specifically the lack of membership of LDCs and SIDS. ${ }^{150}$ This question is fundamental to governance of a loss and damage mechanism. Inclusiveness is extremely important for a loss and damage mechanism having political legitimacy. After the controversies of COP 15, legitimate representation and inclusiveness have been seen as central to creating binding mechanisms. In order for a loss and damage mechanism to prioritise the vulnerable and be truly inclusive it is important that LDCs and SIDS are not only part of the process, but also involved in its governance.

\subsection{Finance and Funding}

Financial commitments are vital to a working loss and damage mechanism. As discussed, the UNFCCC is embedded with notions of financial assistance from developed Annex I and Annex II Parties to developing non-Annex Parties, particularly LDCs and SIDS.

The UNFCCC provides for an official financial mechanism under Article 11, which has entrusted the Global Environmental Facility and more recently the Green Climate Fund (henceforth 'GCF'). Three other funds have been established under the UNFCCC: the Least Developed Countries Fund, the Special Climate Change Fund, and the Kyoto Adaptation Fund. In addition, bilateral, regional, and multilateral channels exist in keeping with developed country funding obligations under Article 11.5. None of these funds specifically provide for compensation, insurance or the type of funding required for a loss and damage mechanism. Article 4.8 makes reference to the types of funding required to address loss and damage and a broad reference to all 'necessary' actions. However, it does not state whether financing such action must come through the UNFCCC financial mechanism, leaving open whether loss and damage funding under Article 4.8 is through the current UNFCCC funding mechanisms or other channels.

\footnotetext{
${ }^{150}$ IISD, 'Summary of the Bonn Climate Change Conference: 4-15 June 2014' (Earth Negotiations Bulletin, 12:598) <www.iisd.ca/download/pdf/enb12598e.pdf> accessed 14 August 2014.
} 
The greatest hope in climate funding remains the ambitious GCF, where a funding commitment was made through the 2009 Copenhagen Accord for developed countries to collectively pledge “new and additional” funding of US\$100 billion per year by 2020 for climate action in developing countries. ${ }^{151}$ Though the initial pledge was meant to assist mitigation and adaptation actions, the GCF itself could include funding for loss and damage. ${ }^{152}$ The GCF receives guidance from the COP, including on matters relating to policies, programmes, priorities and eligibility criteria. ${ }^{153}$ The GCF Board then approves such actions and can also approve thematic windows of substructure to address specific activities (such as for loss and damage). ${ }^{154}$

The other major issue is raising climate finance itself. Climate funding overall, whether through the GCF or alternative streams has remained far below what is required. A World Bank report suggests that fundraising for mitigation and adaptation have been woefully inadequate, standing at less than 5 per cent of projected needs. ${ }^{155}$ Here the role of 'responsibility' and 'liability' are stressed. A major deficit in current climate financing can be traced to the fact that most funds are voluntary. The UNFCCC must make financial contributions obligatory for loss and damage. There is a fundamental conceptual difference between giving voluntary 'aid' type payments into a fund and obligatory payments based on liability. As outlined in this paper, state and civil liability regimes provide examples of how to address loss and damage. The framework developed in this paper demands a clear delineation between responsibility and vulnerability, which works under a liability approach. Verheyen and Roderick have suggested that financial limits, such as ceilings on liability, caps relative to GDP, tiered financial limits, and time limits, such as limiting claims based on damage after a certain year, can provide compromises to parties. ${ }^{156}$ Such options

\footnotetext{
${ }^{151}$ UNFCCC, Decision 1/CP. 15, ‘Copenhagen Accord’ (30 March 2010)

UNFCCC/CP/2009/11/ADD.1, para 8.

152 ibid para 10.

153 UNFCCC, Decision 3/CP.17, 'Launching the Green Climate Fund'(15 March 2012)

UNFCCC/CP/2011/9/ADD.1, article 4, p. 58.

154 ibid 18(h) at 60.

155 World Bank, World Development Report 2010, (Washington DC: USA, 2010) 257

<siteresources.worldbank.org/INTWDR2010/Resources/5287678-1226014527953/WDR10-FullText.pdf $>$ accessed 13 July 2013.

${ }^{156}$ Roda Verheyen and Peter Roderick for WWF-UK, 'Beyond Adaptation: The Legal Duty to Pay Compensation for Climate Change Damage,’ (November 2008)

<assets.wwf.org.uk/downloads/beyond_adaptation_lowres.pdf> accessed 20 August 2013.
} 
are in line with both the 1991 and 2008 Proposals by AOSIS; many examples are shown in the discussion of environmental liability schemes in section 3.

One recent proposal is for a loss and damage mechanism funded by levies paid by major polluting companies, based on their emission to date and on future extraction of fossil fuels. ${ }^{157}$ Such proposals seek to fill the 'funding gap' around loss and damage through identifying large polluting companies as 'responsible parties' under the no-harm rule. The Carbon Majors Proposal also borrows the idea of a levy and polluter pays from the CLC, referred to in Section 4.3. The Carbon Majors Proposal still leave a number of considerations under an ethical and legal framework, such as how international legal principles of CBDRRC are dealt with (as several large oil polluting companies being from developing countries) and how one ensures that the levy is punitive or reparative (from a transitional justice point of view) rather than merely being subsumed as a 'small tax' by a corporation.

Nevertheless, the Carbon Majors Proposal does present a strong starting point, in line with an ethical and legal framework, for State Parties to consider how to provide adequate finance for a loss and damage mechanism. It could also be the basis of a civil liability regime for global warming.

\subsection{Centring the moral claim}

The UNFCCC includes important principles based on environmental ethics and equity under Article 3, many of which have been referred to throughout this paper. However, in recent years technical and economic debates rather than the deep moral issues at stake have dominated the climate regime. ${ }^{158}$ The populations that face 'life and death' questions because of the impacts of climate change are often marginalised in such debates. Therefore, centring the moral claim of loss and damage and the principles articulated in Article 3 of the UNFCCC is important for an international mechanism. This is not to de-emphasise science or economics, but rather re-emphasis the ethical

\footnotetext{
157 Julia Richards and Keely Boom, Carbon Majors Funding Loss and Damage (June 2014) <www.boell.de/sites/default/files/carbon_majors_funding_loss_and_damage_kommentierbar.pdf> accessed 2 July 2014.

158 Jamieson (n 69).
} 
principles which were written into international documents several decades ago with more enthusiasm.

The inclusion and participation of civil society has been an important feature of the UNFCCC, mandated through Article 7.6 of the Convention. Since 1992, the COP has seen the participation of nearly one hundred thousand delegates, with over half from civil society representing over 1300 NGOs. ${ }^{159}$ NGOs cover a broad spectrum of society's interests, including environment, sustainable development, business, energy, and education. ${ }^{160}$ The UNFCCC does in this regard have the institutional framework and experience to ensure a participative loss and damage mechanism as much as any international regime.

However, gaps remain in the UNFCCC process. Since 1992 environmental NGOs, business NGOs, and research organisations have made up nearly two-thirds of NGO participation. ${ }^{161}$ In contrast, indigenous peoples groups and women's groups participated less than other organisations, including religious organisations. In addition, ‘trade union NGOs' represented less than 1 per cent of the proportion of participation. ${ }^{162}$ A preliminary scan of such figures indicates that further efforts must be made to enhance a participative approach under the UNFCCC to reach the most vulnerable populations, particularly with respect to a loss and damage mechanism. A deeper analysis of NGO and civil society participation, as well as a theoretical understanding from political science and more critical approaches such as subaltern studies and Third World Approaches to International Law, could provide a way forward for a participative loss and damage mechanism.

\section{Conclusion}

This paper has argued that there is both a moral and legal imperative for a loss and damage mechanism under the UNFCCC. A framework has been outlined based on these underpinnings that can be used to create a truly just and legitimate mechanism

\footnotetext{
${ }^{159}$ Miquel Munoz Cabre, 'Issue-linkage to Climate Change Measured through NGO Participation' (August 2011) 11/3 Global Environmental Politics 10.

160 ibid.

161 ibid.

162 ibid.
} 
to address loss and damage. This framework carefully considers both the moral and legal obligations, as well as the political frameworks that exist.

The UNFCCC remains the focal point to a solution to loss and damage. It provides a global solution to a global problem with local impacts. Other movements, such as Palau's possible ICJ advisory opinion request, could provide a platform for climate liability regime to develop in the future. But given the increasingly marginal timeframes, imminent action is necessary. Some may not favour the slow pace of UNFCCC discussions; however it provides a platform for a mechanism based on political consensus and has many of the frameworks already in place. Implementing a loss and damage mechanism will not happen within one COP. It is an on-going process that requires significant political will and diplomacy from all parties.

Whilst this paper has concentrated on the UNFCCC, it is important to remember that it is not a panacea when it comes to addressing climate change or loss and damage. Rather, an 'all hands on deck' approach is necessary to tackle climate change. This includes radical changes to lifestyles, legal frameworks and lifestyles to ensure mitigation and adaptions requirements. Further, addressing loss and damage needs to 'not become the norm' of climate change negotiations, as substantial mitigation efforts need to occur to prevent the catastrophic consequences of further climate change. However, appropriately addressing this regulatory gap in the UNFCCC could flow on to enhance the mitigation efforts necessary. 